\title{
JEDNODEJSTVOVÁ HRA V SLOVENSKEJ MODERNISTICKEJ DRÁME NA ZAČIATKU 20. STOROČIA (NA PRÍKLADE HIER VHV A VHS) ${ }^{1}$
}

\section{One-act Play in Slovak Modernist Drama at the Beginning of the $20^{\text {th }}$ Century (on Example of Plays by $\mathrm{VHV}$ and $\mathrm{VHS}$ )}

Keywords: Slovak modernist drama, VHV, VHS, Christmas, one-act play, symbolism

Contact: Slovenská akadémia vied; katarina.cupanova@savba.sk

Jednodejstvová hra ,sústred’uje svoj dramatický materiál na jedinú krízu alebo na jedinú výraznú epizódu (...). Jej rytmus je vel'mi rýchly, pretože dramatik pracuje iba s alúziami na situáciu a pri vykresl'ovaní prostredia iba s úspornými realistickými detailmi“ (Pavis 2004: 220). Ako samostatný žáner sa objavila na začiatku 19. storočia, ale k jej rozvoju došlo najmä na jeho konci (Maurice Maeterlinck, Oscar Wilde či August Strindberg, na Slovensku napríklad Ferko Urbánek či Jozef Gregor Tajovský). Dráme, v podobe jednoaktoviek, ako modernisticky emocionálne vypätých a exaltovaných fragmentárnych scén, sa v prvom desat'ročí 20. storočia, ale aj neskôr sústredene venoval iba Vladimír Hurban Vladimírov, ktorý svojimi ranými textami (Vianoce, 1904; Ked' sa schladí, 1905; Kupci, 1906; Boj, 1907) narúšal dovtedajšiu tradíciu slovenskej realistickej dramatiky. Autorom modernistickej dramatickej skice Vianoce (1908) je však aj Vladimír Hurban Svetozárov, svojej jedinej divadelnej hry.

\section{VHV}

Vladimír Hurban Vladimírov (1884-1950, vl. m. Vladimír Konštantín Hurban, pseudonym VHV) bol v slovenskej literárnej histórii dlhé roky považovaný za jedného z prvých modernistických dramatikov. Toto zaradenie však bolo založené len na celovečerných hrách (Milica Nikoličová 1922, Zem 1926, Zámka škripí 1941), ktoré kritici vysúvali do popredia. Dramatické začiatky VHV sa však nesú v znamení

\footnotetext{
${ }^{1}$ Štúdia je výstupom grantového projektu VEGA 2/0066/20 Modernizmus v slovenskej literatúre II. Zodpovedný
} riešitel' Mgr. Michal Habaj, PhD. Doba riešenia: 2020-2023. 
jednoaktoviek a iných kratších dramatických foriem. Práve rané dramatické „etudy“ VHV sa stali východiskom modernistických snáh autora. Malé formy a krátke žánre s oslabeným dejom charakteristické pre súdobé modernistické smery. Význam nadobúda najmä prvok fragmentárnosti, ktorý sa u VHV prejavil novými typmi krátkych dramatických žánrov ako ranný diškurz (Kupci 1906), scéna (Dokončenie 1905), fonografická snímka (Na robotu 1907), kresba (Naša 1905), rozpomienka (Ked’ sa schladi 1905) či schéma z podvečera (Boj 1907). V kontexte jeho celoživotnej tvorby tvoria krátke dramatické žánre významnú čast’.

Príklon VHV k modernému divadlu sa spája s obdobím jeho štúdii, kedy mal možnost' vidiet' stovky predstavení svetových klasikov aj súvekých autorov v podaní srbského divadla v Záhrebe, vo Viedni a v Bratislave (Pašteka 1990: 239). Vychovaný svetovými mestskými divadlami sa VHV odlišoval od súdobých slovenských dramatikov, čo si všimol napokon aj Štefan Krčméry (Krčméry 1955: 254). VHV tak absorboval vplyvy ibsenovské, čechovovské aj maeterlinckovské. Rozhodujúcim momentom pre umelecké formovanie VHV bolo najmä umelecké ovzdušie a divadlá vo Viedni, ktoré spôsobili, že hl'adal nové umelecké cesty.

Tie kritika prijala rôzne, napríklad usúdila, že išlo len o „nenáročné a málo vydarené pokusy, ktoré nemohli viest' $\mathrm{k}$ nijakému úspechu a boli viac cvičením než umeleckou tvorbou“ (Hamaliar 1929: 222). V porovnaním s Tajovským písal „odlišne“, čím „opustil vyšliapané chodníčky našej dramatiky“ (Mráz 1934: 100). A. Mráz neskôr videl vo VHV takmer tragický príbeh dramatika, ktorý stroskotal v dolnozemskom dedinskom prostredí. Jeho úsilie charakterizoval ako „experimentovanie“, ktorému však „nedal plný dramatický tvar. (...) Jeho aktovky spred vojny boli u nás novotou, dráždili pozornost' svojím sviežim koloritom, dejovou vystupňovanost'ou, lyricky kultivovane sfarbeným štýlom, no cítilo sa, že tieto pokusy Hurbanove nie sú súce pre náš repertoár“ (Mráz 1975: 18).

\section{Vianoce (VHV)}

Hra Vianoce vyšla v roku 1904. Oproti ostatným raným hrám VHV je kompozične rozsiahlejšie, rozdelená na tri obrazy: Prekvapenie, Radost' a Upomínanie. Tie sú navzájom oddelené dlhými časovými pauzami, ale každý z nich sa odohráva na Štedrý deň. Toto rozdelenie umožnilo VHV kondenzovat' dramatický čas a vytvorit' priestor pre konfrontáciu medziludských vzt’ahov. Ďalším spoločným prvkom je ústredná melódia, ktorá sa objavuje v pozadí každého obrazu, pieseň Čas radosti, veselosti z obradového repertoáru l'udovej kultúry o harmonickom prežívaní vianočných sviatkov. Jej posolstvo postavil autor do kontrastu s tragickým prebiehajúcim dejom. 
Prvý obraz (Prekvapenie) ukazuje tradičnú vianočnú idylu v meštianskej rodine, ktorú tvorí otec, matka a ich tri deti - Igor, Milan a Lumíra. Dej sa odohráva v izbe so širokými dverami do salónu v úzadí, ktoré otvárajú priestor a poskytujú možnost' vykročenia z obmedzenej plochy javiska. Vianočný „,̌̌as radosti““ a až biedermeierovsky idealizovaný motív rodiny narúša nedorozumenie medzi rodičmi. Otec v snahe prekvapit' rodinu zatají pred manželkou kúpu vianočného stromčeka. Matka dáva sklamanie neustále najavo a v rodinnej idyle narastá disharmónia. Obraz dopĺn̆a aj komická scénka pána Pentlíka, ktorý sa v šiestom výstupe pasuje s privel'kým stromčekom a usiluje sa ho pretlačit' cez dvere do salónu. Kl’účovým prvkom obrazu je záverečný moment prekvapenia - z odhalenia vianočného stromčeka, z výhry „tabákového losu“ aj z príchodu ujca Janka.

V druhom obraze (Radost') dochádza $\mathrm{k}$ narúšaniu idyly $\mathrm{v}$ otcovskom dome. Dcéra Lumíra sa z javiska vytráca (jej absenciu Igor pripisuje diet'at'u a predvianočným prácam) a namiesto nej sa objavuje Mája. Rodičia očakávajú návrat syna Igora zo štúdii. Igor sa vracia domov ako promovaný lekár a zasnúbi sa s Májou. V rovnakom čase sa domov vracia aj Igorov brat Milan, ktorý kvôli nešt’astnej láske strávil niekol'ko rokov v psychiatrickom ústave. Neuvedomuje si však, že strávil roky v liečebni a nie vo väzení. Predzvest'ou dramatického konfliktu sa stáva rozhovor (intermezzo) dvoch slúžok v štvrtom výstupe, z ktorého sa čitatel' dozvedá o príčine Igorovho nešt'astia. Milanova niekdajšia láska Elenka a Igorova súčasná snúbenica Mája boli sestry, čo predznamenáva ich budúcu zámenu. Milan vidí v bratovej snúbenici svoju stratenú lásku. Pod vplyvom vypätej situácie vytiahne revolver a vystrelí na otca, ktorého považuje za strojcu svojho nešt’astia. Otec umiera, avšak na srdcový záchvat. Zatial' čo Igor plače nad otcom, Milan prechádza škálou emócii: „,Milan (hned' po výstrele). Tak! (Revolver mu vypadne z ruky, pomäteno.) Vlk! Chcel ma zest'. (Obzre sa po izbe.) Čo? (miernejšie) stromčok? (Radostne). Áno, dnes je štedrý večer (celkom pokojne). Aký som veselý! “(VHV 1904: 27). Podobný motív je možné vidiet’ v Strindbergových rodinných drámach (napr. Otec 1887) - Michal Babiak píše dokonca o fascinácii „Strindbergom (rodina ako skryté ohnisko formovania deštrukčných vzt’ahov) a Ibsenom (skrývaná minulost’ ako príčina aktuálnej deštrukcie)““ (Babiak 2011: 123).

Tretí obraz (Upomínanie) je spomienkou na predchádzajúce udalosti, dej je však zasadený do inej, elegantne zariadenej izby. Manželstvo Igora (Muža) a Máje (Ženy) je po troch rokoch poznačené minulost’ou, obaja sa obávajú straty lásky toho druhého. Medzil'udská dráma sa prenáša do vnútorného sveta postáv. Igor a Mája si uvedomujú zmenu ich vzt'ahu - on sa nevie zmierit' so smrtou otca a Štedrý deň je preňho jej bolestnou pripomienkou. Igor cíti emocionálnu rozpoltenost' a nedokáže sa jej bránit'. Mení sa aj citové naladenie manželov. Igor sa Máji odcudzuje, ked’ sa dostáva do pozície 
muža neschopného citu voči vlastnej žene: „Naozaj-ja necítim nič. “(VHV 1904: 38). Neschopnost' vnímat' emocionálne stavy svoje aj iných, estetická necitlivost' (Welsch 1993: 10), ktorú pozorujeme u Igora, je jedným z charakteristických emocionálnych inštrumentárí modernistickej dramatiky. Záver upozorňuje na pravý zmysel Vianoc, ktorým je nielen oslava narodenia Krista, ale aj hl'adanie vzájomnej lásky. Hra končí zmierením manželov. VHV zbavuje postavy erotickej (fyzickej) lásky a nahrádza ju láskou duševnou (duchovnou).

Za prvý signál modernistických tendencií $\mathrm{v}$ texte možno považovat' zmenu v označení dvoch hlavných postáv v tret'om obraze. V prvom a druhom obraze majú hlavné postavy konkrétne mená - Igor a Mája, ale v tret’om obraze sú tieto postavy uvedené len všeobecnými pomenovaniami - Muž a Žena. Michal Babiak sa v tejto súvislosti zaoberá otázkou, či chcel VHV zdôraznit' vývinový oblúk postáv, alebo má táto premena symbolizovat' prerod autora $\mathrm{z}$ konzervatívneho teológa na dekadentného modernistického provokatéra (Babiak 2011: 123). Dôvod však bol jednoduchší: upretím mena odobral VHV postavám ich identitu a ponechal im len základnú, zovšeobecnenú podstatu (Muž a Žena).

Názov hry obsahuje nielen realistickú a časovo určujúcu, ale aj symbolickú rovinu. Pomenovanie Vianoce je spojené s konvenčnou predstavou o harmonickom období, ktoré však narúšajú tragické udalosti. V hre stoja proti sebe symbolická rovina krest'anskej tradície a realistický svet. Vianoce ako sviatky pokoja kontrastujú so zložitou a napätou situáciou v rodinnom kruhu. V tomto zmysle sú Vianoce ironickým názvom, ktorý symbolizuje zahládzanie hlbokých medziludských rozporov tradičnými zvyklost’ami. Rovnako silný tón dramatického rozporu medzi pomenovaním a skutočnost'ou v sebe nesie aj názov druhého obrazu Radost'.

Z hladiska štruktúry postáv dominujú viaceré kontexty - kontext rodiny (harmonický obraz rodinného života v prvom obraze), kontext syna (Milan Rudinský je zničený smrt’ou svojej niekdajšej lásky Eleny, s ktorou sa mu otec nedovolil oženit') a kontext manželov (Igor a Maja trpia minulost'ou rodiny a hl'adajú si k sebe cestu). Minulost' sa však vráti a má za následok tragické zrážky. Postavy ostatných rodinných príslušníkov (otec, matka, sestra a i.) stoja kontextovo na okraji. Vianoce sú hrou, ktorá je zal’udnená postavami oproti autorovým ostatným jednoaktovkám. Podla Júliusa Pašteku je druhý obraz hry dokonca taký sujetovo obsažný, že by sa mohol rozpracovat' na samostatnú hru (Pašteka 1990: 241).

Hra Vianoce je sociálnou drámou, ktorá demaskuje tradičný obraz harmonickej rodiny ako základu spoločnosti. Ešte stále však zachováva priamočiary sled udalostí. Východiskom pre dramatickost' sú najmä disharmonické medzil'udské vzt’ahy. Pozíciu 
hry v dobovom kontexte určuje nový spôsob podania, čo možno vidiet' najmä v expozícii, na budovaní dramatického konfliktu a pri charakterizácii postáv. Do popredia vystupuje psychologická hĺbka protagonistov, ktorá zvýrazňuje inovačný ráz hry.

\section{VHS}

Popri VHV sa v slovenskej predprevratovej dramatike vyskytol d'alší výrazný modernista, Vladimír Hurban Svetozárov (1883-1949, vl. m. Vladimír Ladislav Hurban, pseudonym VHS) bol v slovenskej literárnej histórii pomerne dlho prehliadaný, a to aj napriek tomu, že bol prekladatel'om Goetheho, Rostanda a Bjørnsona. Na formovanie umeleckej metódy VHS tak mali vplyv nielen prekladatel'ské skúsenosti, ale aj mnohostranné zahraničné kontakty a inšpiračné zdroje (nemecké, francúzske, ruské a severské). Ťažiskovo pôsobil najmä v modernizujúcej poézii a jeho básnická tvorba bola slovenskou literárnou históriou pomerne vysoko hodnotená (Michl 1970: 256, 325-326). Medzi modernistických autorov sa zaradil už ako básnik a prozaik v roku 1901 časopisecky debutoval novelou Sólo, pozoruhodná bola aj jeho neskoršia novela Búrka z roku 1914, v roku 1908 publikoval sedem básní v časopise Dennica. Po prvej svetovej vojne sa tvorivo odmlčal.

\section{Vianoce (VHS)}

Dramatický náčrtok s názvom Vianoce ${ }^{2}$ je jedinou publikovanou hrou VHS. Pre žáner náčrtku sa rozhodol pravdepodobne pod vplyvom zahraničných vzorov (M. Maeterlinck, O. Wilde, A. Strindberg) a príklonom k modernisticky koncipovanému krátkej dramatickej forme sa usiloval tvorit' v súvislosti s novými žánrovými preferenciami európskej dramatiky. Do popredia sa dostáva fragmentarizácia ako charakteristický modernistický prvok zdôrazňujúci nedokončenost'.

Náčrtok pozostáva z jednej scény, jeho dej je časovo pomerne krátky (odohráva sa v priebehu jedného večera) a vystupujú v ňom len tri postavy. Vianoce VHS sú však tematicky aj ideovo komplexnejším textom ako rovnomenná hra VHV. Hru VHS charakterizuje psychologický ponor do vnútra postáv, kde sa odohráva základný dramatický konflikt. Ústredným motívom je záhadná spoločná minulost' dvoch hlavných protagonistov.

Dej sa opät' odohráva na Štedrý deň. Eva zdobí vianočný stromček, ked' za dverami do izby začuje Hlas. Eva v mužovi spoznáva kedysi blízkeho človeka.

\footnotetext{
${ }^{2}$ Hurban, V. S. Vianoce. Národnie noviny. 24. 12. 1908 (152/39), s. 4-5.
} 
Rozhovor postáv je spočiatku formálny a obmedzuje sa na bežné zdvorilostné frázy, postupne sa však preklápa do monológu muža o neschopnosti cítit' a prežívat' emocionálne stavy a o negácii života. Eva Neznámemu viackrát naznačí, že mu nerozumie. Náhle ho osloví menom a z Neznámeho sa na okamih stáva Viktor. Tento moment predstavuje výrazný zlom $\mathrm{v}$ komunikácii postáv a ich rozhovor sa stáva osobnejším, je plný narážok a nejasných, nedopovedaných náznakov. Následný dialóg však odhalí len čast' ich spoločnej minulosti - spoločný citový život ostane takmer úplne skrytý. Evu a Neznámeho spája nenaplnený lúbostný vzt’ah: „,Neznámy: Ja odišiel som. Zmizol som, zanechajúc vás v zenite nášho pomeru. Zmizol som bez stopy. Nedal som vám slova vediet'. Ja vedel som, že vám tým zasadím ranu, pre ktorú ešte dnes choriete. Ja vedel som, že vy sa nevydáte. “ (Hurban 1908: 5). Na strane Evy je stále vidiet’ nádej v obnovenie vzt’ahu, ale zo strany Neznámeho to už neprichádza do úvahy. Prehovory Neznámeho sa menia na osobnú spoved' muža, ktorého ,nepokoj v moment štedrého večera " (Hurban 1908: 5) bol impulzom k návratu k Eve. Nádej na vzájomný kontakt sa však vytráca. Neznámy podáva Eve ruku a ako nečakane prišiel, rovnako aj odchádza. Eva „najprv ako omráčená stoji“ (Hurban 1908: 5), potom beží za Neznámym. Ked” sa po chvíli vráti na javisko, je úplne zmenená.

Poučenie technikou modernej drámy u VHS možno spájat' s motívom prenesenia zlomového momentu na viacero postáv. Ide o tzv. drámu duší, ako ju vypracovali symbolisti (M. Maeterlinck, H. Ibsen, A. P. Čechov). Stretnutie dvoch l'udí vyjadruje rozpad medzil'udských vzt'ahov a neschopnost' vzájomnej komunikácie. Pomenovanie Neznámy môže byt' nálepkou zakrývajúcou pravú identitu postavy, ale rovnako aj synonymom pre „nepoznanýc, teda ten, o ktorom sa nič nevie. Stratou spojenia postavy so svojou občianskou identitou sa hra stáva pesimistickým obrazom o l'udskej samote a odcudzení. Vonkajší dej je takmer úplne potlačený a dramatická akcia redukovaná len na dialóg dvoch odcudzených postáv so spoločnou, no neznámou minulost'ou. Z hl'adiska dramatických prehovorov dáva VHS prednost' zámlkám a náznakom pred realistickým dialógom, čím zvyšuje významové napätie textu. Dejové napätie sa stupňuje tak, že vo chvíli, ked' intenzita deja dosahuje vrchol, intenzita akcie a dialógu viditel'ne poklesne (Veltruský 1999: 85-97). Ked’že obmedzené prehovory postáv nemôžu zachytit' charakteristiku času a miesta, kostýmy, fyzické konanie postáv, ich mimiku, intonáciu a d’alšie okolnosti deja (Drozd 2013: 25), VHS využíva v hre množstvo detailných scénických poznámok, ktoré rozsahom prakticky tvoria vedlajší text hry.

Výrazným modernistickým prvkom je pôsobenie na všetky zmysly čitatel'a. Dôraz sa kladie najmä na symboliku svetla. To v hre slúži na významové zosilnenie vnútorných psychologických procesov postáv. Na začiatku hry Eva zapáli sviečky na 
stromčeku a obe lampy v miestnosti. Ked' chce posilnit' nádej na obnovenie vzt'ahu s Neznámym, zapal'uje d'alšie sviečky: „Počkajte, sviečky nám vyhášajú na stromčeku. Mám ešte, dáme nové. Áno? “ (Hurban 1908: 5). Ked’ však Neznámy odíde, Eva „, zaháša jednu sviecu po druhej “ (Hurban 1908: 5) a nakoniec prikáže služobnej: „Zahas lampu. Už prešly Vianoce. “ (Hurban 1908: 5). Miera svetla tak korešponduje s podnetnost'ou dialógu a Eviným vnútorným prežívaním. Július Pašteka v tejto súvislosti predpokladá, že „scénické prostriedky zrejme poslúžili autorovi na vonkajšiu, optickú sémantizáciu dramatického textu sugestívneho práve významovou neurčitost'ou a nedopovedanost'ou“ (Pašteka 1990: 254). Zvuky vianočných kolied za scénou kontrastujú s tlmeným rozhovorom Evy a Neznámeho, plejádu podnetov dopín̆a vôňa vianočného stromčeka či slávnostnej večere.

V rámci vertikálnej dramatickej kompozície hry VHS použil metódu mnohovrstvovej štruktúry symbolistických hier. „Vlastné dianie prebieha iba na rovine rozhovoru, ten sa obmedzuje na akt spomínania a na akt analýzy minulosti, čiže je to vyslovene psychické dianie: dialogická interkomunikácia dvoch izolovaných subjektov, ktoré ako konkrétne bytosti nie sú už schopné vzájomne l’udsky komunikovat"“ (Pašteka 1990: 254). Dlhé prestoje medzi prehovormi postáv však možno skôr chápat’ aj ako efektívne stupňovanie dramatického napätia, hoci hru značne spomal'ujú a zhoršujú jej inscenovatel'nost'.

Obe analyzované hry spája názov a časové ukotvenie. Hry s vianočnou tematikou sa v slovenskej dramatike vyskytovali v podobe tzv. betlehemských hier už od stredoveku a v nezmenenej podobe sa zachovali až do 19. storočia. Na začiatku 20. storočia sa začali objavovat' prvé pokusy o prekonanie ich archetypálnej podoby, a tým preformovat' ich pôvodnú náplň. Ústredným motívom hier už nie je biblický príbeh o narodení Krista, ale téma Vianoc ako sviatkov radosti, pokoja a lásky, na ktoré sa viažu l'udské príbehy. VHV v hre Vianoce použil trojnásobný pohl'ad do jednej rodiny na zobrazenie premenlivosti l'udských vzt'ahov. VHS vo svojich Vianociach zase spojil moment vianočného nepokoja s analytickým pohl'adom do minulosti dvoch postáv.

Obe hry nadväzujú na nový typ tzv. symbolistickej drámy (určenej najmä tvorbou Henrika Ibsena), ktorá zovšeobecňuje pojem symbolu a kóduje ho do reality - ide o pokus skonštruovat' na javisku svet, ktorý si požičiava prvky z viditel'nej skutočnosti, ale ktorý diváka prostredníctvom herca odkazuje na inú skutočnost', ktorú divák musí objavit' (Pavis 2004: 397). Zatial' čo VHV sa prikláňal k realistickému pólu ibsenizmu a v jeho línií smeroval k vytvoreniu rodinnej drámy, VHS si pre svoj dramatický náčrtok vybral z Ibsena subjektivistickú zložku, blízku symbolistickému modernizmu. V hre 
VHV Vianoce pretrvávajú prvky realistickej zobrazovacej metódy, ale témou, motívmi, výrazovými prostriedkami a charaktermi postáv sa posúva $\mathrm{k}$ modernej dramatike. U oboch autorov sa symbolizmus prejavuje aj v štruktúre a motívoch. V kompozícii a charakteroch sú obaja autori minimalistickí (krátka dramatická forma, redukcia postáv, náznakový dialóg). Obidve hry stoja na ibsenovskom princípe determinácie prítomnosti minulost’ou, ktorá vyúst’uje do krízovej situácie. K modernizačným postupom patrí aj zhutnenie zápletky, prudké vyostrenie dramatického konfliktu a téma medzil’udskej komunikácie.

\section{Summary}

Presented article includes an analysis of two one-act plays of the same name-Christmas (1904) written by VHV and Christmas (1908) written by VHS. Both plays represent a new type of symbolist drama. The analysis shows how both plays approach European modernist drama (symbolism of light, short dramatic form, characters reduction, hint dialogue, compacting the plot, sharpening the dramatic conflict and opening up the topic of interpersonal communication).

\section{Literatúra}

Babiak, M. Vladimír Hurban Vladimírov. In: Štefko, V. et al. Dejiny slovenskej drámy 20. storočia. Bratislava: Divadelný ústav, 2011, s. 121-143.

Drozd, D. Kapitoly z teorie dramatu. Olomouc: UPOL, 2013.

Hamaliar, J. I. Hlasy nášho východu. Praha: Leopold Mazáć, 1929.

Hurban, V. S. Vianoce. Národnie noviny. 24. 12. 1908 (152/39), s. 4-5.

Krěméry, Š. Výber z diela IV. Bratislava: SVKL, 1955.

Michl, J. B. Bjørnstejerne Bjørnson. Bratislava: Obzor, 1970.

Mráz, A. Pät'desiatročný VHV. Naše divadlo. 1934 (7/7), s. 100-102.

Mráz, A. Pohl’ady na slovenskú drámu. Bratislava: Slovenský spisovatel', 1975.

Pašteka, J. Slovenská dramatika v epoche realizmu. Bratislava: Tatran, 1990.

Pavis, P. Divadelný slovnik. Bratislava: Divadelný ústav, 2004.

Veltruský, J. Drama jako básnické dílo. Brno: Host, 1999.

VHV Vianoce. Liptovský Svätý Mikuláš: Klimeš a Pivko, 1904.

Welsch, W. Estetické myslenie. Bratislava: Archa, 1993. 